\title{
EVALUASI PENGENDALIAN INTERNAL DALAM PELAKSANAAN KEGIATAN PADA DINAS SOSIAL PROVINSI LAMPUNG
}

\author{
Rina Karya Wardani ${ }^{(1)}$, Ahiruddin $^{(2)}$, Novalia ${ }^{(3)}$ \\ Fakultas Ekonomi Universitas Sang Bumi Ruwa Jurai \\ wardani_rina69@yahoo.co.id,ahiruddin@fe.saburai.ac.id,novalia@fe.saburai.ac.id
}

\begin{abstract}
Abstrak. Evaluasi Pengendalian Internal Dalam Pelaksanaan Kegiatan Pada Dinas Sosial Provinsi Lampung merupakan penelitian kualitatif yang bertujuan untuk mengetahui pelaksanaan dan hasil evaluasi Sistem Pengendalian Internal Pemerintah dalam pelaksanaan kegiatan yang telah diterapkan pada Dinas Sosial Provinsi Lampung. Metodologi yang digunakan adalah penelitian deskriptif kualitatif. Teknik pengumpulan data yang digunakan adalah melalui observasi, wawancara dan dokumentasi. Informan dalam penelitian ini yaitu Kasubag Perencanaan, Kasubag Umum dan kepegawaian, Kasubag Keuangan serta pegawai secretariat dan bidang teknis. Hasil penelitian ini menunjukkan Sistem Pengendalian Internal Pemerintah Dalam Pelaksanaan Kegiatan Pada Dinas Sosial Provinsi Lampung telah efektif dan memadai namun belum maksimal, ditandai dengan Dinas Sosial Provinsi Lampung telah mengatur wewenang dalam pemberian otorisasi untuk pejabat berwenang, serta kurang efektifnya dalam pencapaian indikator kinerja dan kurangnya SDM dalam pencapaian indikator kinerja. Sebaiknya Dinas Sosial Provinsi Lampung mengadakan evaluasi secara berkala atas pengendalian pelaksanaan kegiatan dan menambah sumber daya manusia yang berkompeten agar dapat menciptakan sistem pengendalian yang baik, birokrasi yang bersih dan bebas dari korupsi, kolusi dan nepotisme.
\end{abstract}

Kata kunci: Evaluasi, Kualitatif, Internal, Pengendalian.

\section{PENDAHULUAN}

Pandangan masayarakat umumnya membentuk suatu pengertian tertentu dalam dinamika perkembangan kehidupan masyarakat, bahkan dapat mengembangkan prinsip atau pengertian tertentu menjadi lebih luas atau lebih rinci. Terjadinya tuntutan masyarakat terhadap kualitas pemerintahan yang lebih baik, mendorong pemerintah pusat dan daerah untuk menerapkan akuntabilitas pubik. Berhasil atau tidaknya kinerja pemerintah daerah dalam menjalankan fungsinya dapat dilihat dari laporan keuangan yang disajikan oleh pemerintah daerah yang juga dapat dijadikan sebagai dasar pertanggungjawabannya terhadap publik.

Faktor lain yang mampu mempengaruhi guna meningkatkan kinerja pemerintah dalam menerapkan anggaran berbasis kinerja, yakni dengan diperlukan peningkatan pengendalian intern pemerintah. Pengendalian dalam pelaksanaan anggaran dapat meningkatkan kinerja pemerintah untuk mendapatkan target yang sudah ditentukan bersama, pelaksanaannya harus dengan sungguhsungguh dan transparan.

Pengendalian internal merupakan salah satu kunci utama sebuah organisasi untuk mencapai tujuannya, baik itu organisasi swasta yang berorientasi pada laba maupun organisasi pemerintah yang bersifat nirlaba. Pengendalian internal menjadi sangat penting bagi suatu organisasi dikarenakan dengan pengendalian internal yang baik, maka kinerja organisasi tersebut juga akan baik, atau dengan kata lain kualitas pengendalian internal yang baik akan akan meningkatkan kinerja para anggota organisasi untuk mencapai tujuan yang telah ditetapkan. Pentingnya pengendalian internal dalam mencapai tujuan organisasi juga dijelaskan oleh arfianti (2011) yang menyatakan bahwa kualitas pengendalian 
intern yang dipengaruhi oleh sumber daya manusia dan teknologi informasi akan mampu membantu suatu organisasi untuk mencapai suatu tujuan tertentu.

Untuk merealisasikan tujuan dan sasaran penyelenggaraan kesejahteraan social Dinas Sosial Provinsi Lampung selama lima tahun kedepan perlu strategi dan kebijakan yang tepat dalam menghadapi tantangan dan hambatan dan mampu memberikan panduan yang dapat menjadi arahan segenap komponen aparatur Dinas Sosial Provinsi Lampung dalam menjalankan tugas dan fungsinya. Demi mendukung program gubernur dan memenuhi pelayanan terhadap masyarakat maka perlu dilaksanakannya pemantauan seluruh pelaksanaan kegiatan yang menggunakan.

Program dan kegiatan yang telah di rencanakan tidak dapat dijalankan secara optimal manakala tidak tersedianya dana.Dengan demikian sumber pendanaan bagi terselenggaranya program harus juga di tentukan. Indikator Kinerja adalah ukuran keberhasilanyang di capai pada setiap Organisasi Perangkat Daerah ( OPD ) Indikator kinerja atau indikator untuk setiap pelayanan pada bidang bidang kewenangan di selenggarakan oleh organisasi Perangkat Daerah keberhasilan dalam bentuk standar Pelayanan yang ditetapkanoleh masingmasing daerah. Penentapan standar pelayanan merupakan cara untuk menjamin dan meningkatkan akuntabilitas pelayanan pemerintah daerah kepada masyarakat.

Dinas Sosial Provinsi Lampung adalah instansi pemerintah yang memiliki tugas pokok dalam Pembangunan Kesejahteraan Sosial di Provinsi Lampung yang diarahkan untuk menanggulangi kemiskinan dengan segala bentuk manifestasinya, perluasan kerja produktif dan peningkatan integrasi sosial dalam upaya mengurangi jumlah Penyandang Masalah Kesejahteraan Sosial (PMKS). Dinas Sosial Provinsi Lampung sebagai organisasi pelayan publik yang mengelola dana masyarakat, maka sudah sepantasnya jika pemerintah harus mampu memberikan pertanggungjawaban kepada masyarakat melalui laporan keuangannya.

Dinas Sosial Provinsi Lampung juga membutuhkan pengendalian internal untuk efektifitas dan efisiensi pelaksanaan kegiatan demi menghasilkan laporan kinerja dan laporan keuangan yang akuntabel hingga dapat meminimalisir adanya penyalahagunaan dari pihak yang tidak bertanggung jawab. Oleh karena itu sangatlah penting adanya pengendalian internal dilakukan oleh organisasi perangkat daerah.

Pengendalian dan Evaluasi pelaksanaan program dan kegiatan Dinas Sosial Provinsi Lampung yang telah dijabarkan dalam Rencana Kerja Dinas Sosial Provinsi Lampung harus ditingkatkan. Hasil pengendalian dan evaluasi pelaksanaan tersebut disusun dalam Laporan Evaluasi Renja Dinas Sosial Provinsi Lampung. Laporan Laporan Evaluasi Renja itu akan menjadi bukti (prove) pencapaian kinerja bahan perbaikan (improving) pencapaian kinerja Dinas Sosial Provinsi Lampung dimasa yang akan datang.

Menurut penelitian terdahulu yaitu "Evaluasi Sistem Pengendalian Intern (Internal Control) Terhadap Kinerja Dinas Pekerjaan Umum Provinsi Sulawesi Utara" yang dilakukan oleh Julia Christina Turagan (2017) menyimpulkan bahwa pengendalian internal yang diterapkan oleh Dinas Pekerjaan Umum Provinsi Sulawesi Utara telah efektif dan memadai. Realisasi pengeluaran Dinas Pekerjaan Umum Provinsi Sulawesi Utara dari 2013 hingga 2015 telah efektif dengan kata kunci evaluasi, kontrol, internal kinerja dan pembagian wewenang serta tanggung jawab sudah efektif dilakukan. Tujuan dari penelitiannya adalah untuk mengevaluasi sistem pengendalian internal terhadap 
kinerja Dinas Pekerjaan Umum Provinsi Sulawesi Utara.

Penelitian kedua yaitu "Implementasi Sistem Pengendalian Intern Pemerintah (SPIP) dalam Mewujudkan Good Governance pada Dispenda Provinsi Sulawesi Selatan oleh Dian Pertiwi (2016) mengimplikasikan teori Stewardship terhadap penelitian ini dapat menjelaskan eksistensi pemerintah daerah sebagai suatu lembaga yang dapat dipercaya untuk bertindak sesuai dengan kepentingan public dengan melaksanakan tugas dan fungsinya dengan tepat. Hasil penelitian menunjukkan bahwa pada Dispenda Provinsi Sulawesi Selatan sudah menerapkan kelima unsur sistem pengendalian intern pemerintah dengan baik dan berkomitmen untuk memberikan pertanggungjawaban kepada masyarakat baik melalui keandalan pelaporan keuangan, pengamanan asset negara dan ketaatan terhadap peraturan perundang-undangan sehingga tercapainya efektivitas dan efisiensi didalam pelaksanaan kegiatan yang dilakukan demi terwujudnya tata kelola negara yang baik.

Penelitian yang ketiga yaitu "Evaluasi Pengendalian Internal Dalam Pelaksanaan Sistem dan Prosedur Pengeluaran Kas Pada Dinas Koperasi dan UMKM Provinsi Sulawesi Utara" oleh G.Panambunan (2016) yang bertujuan untuk mengevaluasi pengendalian internal dalam pelaksanaan sistem dan prosedur pengeluaran kas pada Dinas Koperasi dan UMKM Provinsi Sulawesi Utara. Hasil penelitian adalah pengendalian internal dalam penerapan sistem dan prosedur pengeluaran kas di Dinas Koperasi dan UMKM Provinsi Sulawesi Utara telah sesuai aturan. Sebaiknya kinerja dan disiplin sumber daya manusia di Dinas Koperasi dan UMKM Provinsi Sulawesi Utara terus dipertahankan dan diterapkan dalam menjalankan tugas dan fungsi sebagai pelayan masyarakat.

Dalam penelitian ini terdapat indikasi adanya permasalahan yang dapat menimbulkan lemahnya pengendalian atas realisasi kinerja kegiatan pada Dinas Sosial Provinsi Lampung. Kurangnya sumber daya manusia dan banyaknya tugas dan fungsi yang diemban oleh Dinas Sosial Provinsi Lampung membuat kurang termonitornya pencapaian indikator kinerja kegiatan anggaran berjalan, yang menjadi fokus permasalahan yakni sebagaimana unsurunsur pengendalian internal menurut PP No. 60 Tahun 2008 tentang Sistem Pengendalian Internal Pemerintah (SPIP), yang antara lain yaitu Lingkungan Pengendalian, Penilaian Risiko, Kegiatan Pengendalian, Informasi dan Komunikasi serta Pemantauan Pengendalian Internal, dengan melihat hal ini peneliti memfokuskan bagaimana pengimplementasian Sistem Pengendalian Internal Pemerintah (SPIP) pada Dinas Sosial Provinsi Lampung dalam pelaksanaan kegiatan untuk mewujudkan tata kelola pemerintahan yang baik.

\section{KAJIAN TEORI}

\section{Pengertian Pengendalian}

Pengendalian (control) merupakan salah satu fungsi yang penting dalam manajemen atau yang lazim diterjemahkan sebagai pengelolaan (manajemen terapan), di samping fungsi-fungsi manajemen lainnya seperti perencanaan, pengorganisasian dan pelaksanaan. Istilah control sebagai fungsi manajemen tersebut di dalam penggunaannya sehari-hari diterjemahkan secara beragam, seperti pengawasan, pengendalian, pengawasan dan pengendalian (wasdal), pembinaan, bahkan dengan padanan kata pemeriksaan. Demikian pula dalam perkembangannya, istilah-istilah tersebut diberikan rumusan pengertian yang berbeda-beda pula. (Suryanajaya:2012)

Pengendalian berada pada tataran operasionalisasi kebijakan yang 
dilaksanakan oleh aparat birokrasi atau pejabat/pimpinan dan seluruh jajarannya pada setiap tingkatan unit organisasi pemerintah. Dalam hal ini di samping melaksanakan fungsi perencanaan, pengorganisasian dan pelaksanaan kegiatan, harus melaksanakan pengendalian agar tujuan organisasi dapat dicapai sesuai dengan kebijakan, rencana, dan atau pedoman yang telah ditetapkan. Apabila ditemukan adanya penyimpangan atau kesalahan dalam pelaksanaan kegiatan, maka pejabat/pimpinan yang bersangkutan dapat segera mengambil langkah tindak lanjut atau mengadakan tindakan korektif. Dengan demikian, pengendalian merupakan fungsi yang melekat (built in) pada setiap tingkatan manajemen.

\section{Sistem Pengendalian Internal}

Pengendalian internal adalah seperangkat kebijakan dan prosedur untuk melindungi aset atau kekayaan perusahaan dari segala bentuk tindakan penyalahgunaan, menjamin tersedianya informasi akuntansi perusahaan yang akurat, serta memastikan bahwa semua ketentuan (peraturan) hukum/undang-undang serta kebijakan manajemen telah dipatuhi atau dijalankan sebagaimana mestinya oleh seluruh pegawai. Dengan adanya penerapan sistem pengendalian internal secara ketat maka diharapkan bahwa seluruh kegiatan operasional dapat berjalan dengan baik menuju tercapainya maksimalisasi kegiatan. Bahkan tidak hanya dari segi operasional saja yang akan berjalan dengan tertib dan baik sesuai prosedur, akan tetapi dari segi finansial juga dapat lebih termonitor dengan baik.

Pada dasarnya, faktor efisiensi dan efektivitas unit/perusahaan merupakan dua hal yang juga merupakan sasaran dari diterapkannya pengendalian internal, karena kalau pengendalian internal tidak berjalan sebagaimana yang diharapkan, maka kemungkinan besar (hampir dapat dipastikan) akan timbul yang namanya inefisiensi (pemborosan sumber daya), yang pada akhirnya tentu saja hal ini hanya akan membebani tingkat profitabilitas (keuntungan) perusahaan (Hery, 2014:189).

Berdasarkan Peraturan Pemerintah Republik Indonesia No. 60 Tahun 2008, Sistem Pengendalian Internal adalah proses yang integral pada tindakan dan kegiatan yang dilakukan secara terus menerus oleh pimpinan dan seluruh pegawai untuk memberikan keyakinan memadai atas tercapainya tujuan organisasi melalui kegiatan yang efektif dan efisien, keandalan pelaporan keuangan, pengamanan aset negara, dan ketaatan terhadap peraturan perundang-undangan.

\section{METODE PENELITIAN}

\section{Objek Penelitian}

Penelitian ini dilaksanakan pada Dinas Sosial Provinsi Lampung yang beralamat di Jalan Basuki Rahmat No. 72 Teluk Betung Utara, Bandar Lampung 35212. Peneliti membatasi ruang lingkup penelitian yaitu Dinas Sosial Provinsi Lampung dengan tujuan agar penelitian ini sesuai dengan yang diharapkan. Waktu penelitian dilaksanakan pada bulan Maret sampai bulan Juli 2020 .

\section{Metode Penelitian}

Penelitian ini merupakan penelitian deskriptif dengan menggunakan pendekatan kualitatif. Penelitian deskriptif adalah penelitian yang mengangkat suatu rumusan masalah yang berkenaan dengan pertanyaan terhadap keberadaan variable mandiri baik hanya pada satu variable saja atau lebih (Sugiyono, 2011:35) sedangkan pendekatan 
kualitatif adalah pendekatan yang digunakan untuk meneliti pada kondisi obyek yang alamiah dimana peneliti sebagai instrument kunci, teknik pengumpulan data dilakukan secara triangulasi, analisis data bersifat induktif/kualitatif, dan hasil penelitian kualitatif lebih menekankan makna daripada generalisasi (Sugiyono, 2011:9), variable dalam penelitian ini adalah pengendalian internal, pengendalian internal terdiri dari 5 unsur yaitu :

1. Unsur Lingkungan Pengendalian

2. Unsur Penilaian Risiko

3. Unsur Kegiatan Pengendalian

4. Unsur Informasi dan Komunikasi

5. Pemantauan

Dalam penelitian deskriptif kualitatif, penulis menjelaskan hasil penelitian secara objektif atau apa adanya berdasarkan pengamatan dari kacamata penulis dan fakta-fakta yang ditemui oleh penulis sendiri.

\section{Metode Pengumpulan Data}

1. Pengumpulan data primer

2. Pengumpulan data sekunder

\section{Teknik Pengumpulan Data}

Teknik pengumpulan data merupakan langkah yang paling strategis dalam penelitian, karena tujuan utama dari penelitian adalah mendapatkan data. Tanpa mengetahui teknik pengumpulan data, maka peneliti tidak akan mendapatkan data yang memenuhi standar data yang ditetapkan. (Sugiyono,2014:224).

Data yang dimaksud dikumpulkan dengan teknik sebagai berikut :

a. Observasi

Observasi adalah studi yang disengaja dan sistematis tentang fenomena dan gejala psikis dengan jalan pengamatan dan pencatatan. b. Studi dokumentasi

Dokumentasi adalah teknik mengumpulkan dokumen-dokumen yang dapat dijadikan data untuk mendukung penelitian. Dokumen sendiri adalah catatan peristiwa yang sudah berlalu, bisa berbentuk tulisan, gambar, atau karya-karya lainnya (Sugiyono, 2011:240).

c. Wawancara/Interview

Wawancara atau interview sebagai suatu pertemuan yang melibatkan dua orang saling bertukar informasi dan ide melalui tanya jawab sehingga menghasilkan sebuah pengertian dan pemahaman tentang suatu topic yang sedang dibahas.

d. Kuisioner (angket)

Kuisioner atau angket merupakan teknik pengumpulan data yang dilakukan dengan cara memberi seperangkat pertanyaan atau pernyataan tertulis kepada responden untuk dijawabnya.

\section{Teknik Analisis Data}

Penelitian ini merupakan penelitian kualitatif, maka sesuai dengan penelitian ini, teknik analisis data ialah analisis deskriptif kualitatif. Langkah -langkah dalam analisis data yaitu sebagai berikut :

a. Reduksi data

Mereduksi data berarti merangkum, memilih hak - hak pokok yang penting, dicari tema dan polanya. Dengan demikian data-data yang telah direduksi akan memberikan gambaran yang lebih jelas dan mempermudah peneliti untuk melakukan pengumpulan data selanjutnya, dan mencari bila diperlukan.

b. Penyajian data

Penyajian data ini dilakukan dalam bentuk uraian singkat, bagan, hubungan 
antara kategori, flowchart dan sejenisnya, atau dilakukan penyajian data dengan teks yang bersifat naratif.

c. Penarikan kesimpulan dan verifikasi Kesimpulan dalam penelitian kualitatif adalah merupakan temuan baru yang sebelumnya belum pernah ada. Temuan dapat berupa deskripsi data gambaran suatu objek yang sebelumnya masih remang - remang atau gelap sehingga setelah diteliti menjadi jelas, dapat berupa hubungan kausal atau interaktif, hipotesis atau teori (Sugiyono, 2014: 245-253).

\section{HASIL DAN PEMBAHASAN}

Dinas Sosial Provinsi Lampung merupakan organisasi publik yang orientasinya ada di bidang kesejahteraan sosial, sebagai penyelenggara sebagai kewenangan pemerintah maupun tugas dekonsentrasi dibidang sosial. Dinas Sosial Provinsi Lampung memiliki peranan yang sangat strategis yakni sebagai pelaksana wajib pelayanan dasar yang berpedoman pada prinsip akuntabilitas, transparansi, efisiensi dan efektif. Selanjutnya peneliti mencoba untuk menyampaikan bagaimana implementasi Sistem Pengendalian Intern Pemerintah (SPIP) tercermin dalan Dinas Sosial Provinsi Lampung.

\section{Lingkungan Pengendalian}

Unsur pertama SPIP yang wajib diimplementasikan pada lingkup instansi pemerintah adalah lingkungan pengendalian. PP Nomor 60 Tahun 2008 mewajibkan pimpinan instansi pemerintah untuk menciptakan dan memelihara lingkungan pengendalian yang menimbulkan perilaku positif dan kondusif untuk penerapan SPIP dalam lingkungan kerjanya melalui hal-hal sebagai berikut : a. Penegakan Integritas dan Nilai Etika Pada Dinas Sosial Provinsi Lampung, seluruh pegawai sudah mengetahui, memahami isi aturan perilaku/standar etika, sanksi hukuman terhadap pelanggaran aturan perilaku/standar etika. Sebagaimana pernyataan ibu Iryanti selaku Kasubag Umum dan Kepegawaian :

"Untuk kode etik sudah dilaksanakan dan ada beberapa pegawai yang telah terkena sanksi. Seluruh pegawai sudah mengetahui, memahami isi aturan perilaku/standar etika, sanksi hukuman terhadap pelanggaran aturan."

Pernyataan diatas menunjukkan dilingkungan Dinas Sosial Provinsi Lampung sudah mengetahui standar etika dan sanksi hukuman terhadap pelanggaran etika.

b. Komitmen Terhadap Kompetensi

Pada Dinas Sosial Provinsi Lampung, setiap tahun mengikuti program pelatihan dan pembimbingan yang berkesinambungan, dan melakukan evaluasi untuk memastikan bahwa seluruh pegawai sudah menerima pelatihan yang sesuai dengan pelaksanaan tugasnya, sebagaimana yang diungkapkan oleh ibu Iryanti :

"Nah itu setiap tahun kita ikut sertakan staf untuk mengikuti diklat terkait dengan pengelolaan keuangan dan barang. Juga melakukan evaluasi untuk memastikan bahwa seluruh pegawai sudah menerima pelatihan yang sesuai dengan pelaksanaan tugasnya."

Pernyataan tersebut menunjukkan sikap yang konsisten terhadap 
penyelenggaraan kegiatan yang dimana tujuan utamanya yakni meningkatkan kompetensi kinerja pegawainya. Hal ini dapat memberikan pengalaman teknis yang luas dalam pengelolaan instansi pemerintah.

c. Kepemimpina yang Kondusif

Sebagaimana pernyataan ibu Haveana selaku Kasubag Perencanaan :

"Kita sendiri telah memiliki komitmen kuat terhadap fungsi tertentu dalam penerapan SPIP seperti fungsi pencatatan dan pelaporan keuangan, dan penyempurnaannya, pengelolaan pegawai, pengawasan intern maupun ekstern."

Pernyataan diatas menunjukkan pada Dinas Sosial Provinsi Lampung, memiliki komitmen kuat terhadap fungsi tertentu dalam penerapan SPIP seperti fungsi pencatatan dan pelaporan keuangan, dan penyempurnaannya, pengelolaan pegawai, pengawasan intern maupun ekstern.

d. Pembentukan Struktur Organisasi yang Sesuai Dengan Kebutuhan

Pada Dinas Sosial Provinsi lampung, terdapat kebijakan yang memberikan kejelasan hubungan dan jenjang pelaporan internal dalam instansi pemerintah, untuk memudahkan pimpinan memperoleh informasi pelaksanaan tugas tanggung jawabnya, saling berkomunikasi, serta pemahaman pegawai terhadap hubungan dan jenjang pelaporan yang telah ditetapkan, hal tersebut didukung dengan pernyataan oleh ibu Haveana :
"Nah kalau itu bisa dilihat dari struktur organisasinya,kalau yang dimaksud itu orientasi dalam konteks pengendalian bisa dilihat di masing-masing bidang pelaksana kegiatan untuk pengawasan secara keuangan maupun secara capaian kinerja."

e. Pendelegasian Wewenang dan Tanggung Jawab yang Tepat

Berdasarkan pernyataan ibu Iryanti: "Yaa itu sama toh wewenang telah diberikan secara tepat sesuai dengan tingkat tanggungjawabnya masingmasing."

Berdasarkan pernyataan diatas pada Dinas Sosial Provinsi Lampung, wewenang telah diberikan secara tepat sesuai dengan tingkat tanggung jawabnya masing-masing, baik pimpinan maupun pegawai melakukan tugas dan tanggung jawab sesuai dengan yang diberikan.

f. Penyusunan dan Penerapan Kebijakan yang Sehat Tentang Pembinaan Sumber Daya Manusia Sebagaimana Pernyataan Ibu Iryanti

"Instansi telah melaksanakan kebijakan dan prosedur pembinaan SDM sejak rekrutmen sampai dengan pemberhentian pegawai, yang mengutamakan kompetensi, etika dan integritas, serta mendorong tercapainya kinerja."

g. Perwujudan Peran Aparat Pengawasan Intern Pemerintah yang Efektif

Berikut adalah pernyataan Ibu Tahrirotul Muyassaroh selaku Kasubag Keuangan :

"Setiap tahun kita melakukan kontrol terhadap pelaksanaan 
kegiatan di bidang maupun UPTD. Melakukan monitoring bagaimana pelaksanaan kegiatan intensifikasi pajak dan kemudian itu penggunaan barang-barang berharga penggunaan inventaris kantor dan sebagainya. Itu setiap tahun kita lakukan kebawah itu dalam hal pembinaannya ke bawah apa-apa yang harus dilaksanakan dalam konteks SPIP tadi supaya ini semua jajaran Dinas Sosial Provinsi Lampung melaksanakan tugas pokok dan fungsinya sesuai dengan koridor SPIP."

Pernyataan diatas menunjukkan pada Dinas Sosial Provinsi Lampung, terdapat mekanisme untuk memberikan keyakinan memadai atas ketaatan, kehematan, efisiensi dan efektivitas pencapaian tujuan penyelenggaraan tugas dan fungsi instansi pemerintah, serta melaksanakan tugas dan fungsi sesuai dengan koridornya.

h. Hubungan Kerja yang Baik dengan Instansi Pemerintah Terkait

Instansi telah melakukan hubungan kerja yang baik untuk mengelola anggaran, akuntansi dan perbendaharaan dan yang melaksanakan tanggung jawab pengendalian lintas instansi, sehingga tercipta mekanisme saling uji dan saling berkoordinasi dan selalu berhubungan dengan APIP Aparat pemeriksa Internal Pemerintah (Inspektorat, BPKP, dan BPK)

\section{Penilaian Risiko}

Unsur kedua dari SPIP yaitu penilaian risiko. Dalam menerapkan penilaian risiko, pimpinan instansi pemerintah berdasarkan PP Nomor 60 Tahun 2008 wajib melaksanakan hal-hal sebagai berikut :

a. Identifikasi Risiko

Pada Dinas Sosial Provinsi Lampung, risiko yang ada pada tingkat pegawai dan pimpinan tingkat menengah menjadi perhatian pimpinan yang lebih tinggi.

b. Analisis Risiko

Instansi memiliki mekanisme antisipasi, identifikasi, dan reaksi terhadap segala bentuk kesalahan, sebagaimana pernyataan ibu Tahrirotul Muyassaroh selaku kasubag keuangan :

"Jadi resikonya disini ini banyak terutama resiko dalam pembuatan surat pertanggungjawaban tapi itu sudah diminimalisir dengan adanya petugas verifikasi, disitu kita bisa tau ada kesalahan atau tidak"

Pernyataan diatas menunjukkan unsur Sistem Pengendalian Intern Pemerintah (SPIP) dalam hal penilaian resiko di Dinas Sosial Provinsi Lampung menunjukkan masih membutuhkan tindak lanjut yang lebih mendalam mengenai strategi operasional yang konsisten mengenai rencana penilaian risiko.

\section{Kegiatan Pengendalian}

Kegiatan pengendalian dalam PP Nomor 60 Tahun 2008 merupakan unsur ketiga SPIP yang wajib diterapkan dalam instansi pemerintah. Kegiatan pengendalian adalah tindakan yang diperlukan untuk mengatasi risiko serta penetapan dan pelaksanaan kebijakan dan prosedur unutk memastikan bahwa tindakan mengatasi risiko telah dilaksanakan secara efektif.

a. Reviu atas kinerja instansi

Pada Dinas Sosial Provinsi Lampung, terdapat reviu atas kinerja 
pegawai dalam hal ini dilaksanakan dengan membandingkan kinerja dengan tolok ukur kinerja yang ditetapkan pada level instansi, aktivitas/kegiatan yang sesuai dengan kebutuhan.

b. Pembinaan sumber daya manusia Pada Dinas Sosial Provinsi Lampung, melakukan pelatihan dan diklat bagi semua pegawai mengenai bagaimana mereka bisa supaya mencapai visi dan misi Dinas, dalam orientasi utamanya yakni meningkatkan kesejahteraan sosial.

c. Pengendalian atas pengelolaan sistem informasi

Berdasarkan pernyataan ibu Iryanti : "Itu kita ada sistem yang tercover dengan jelas semuanya masuk disini dan selalu kami informasikan keluar baik melalui portal kepegawaian mengenai misalnya kegiatan pengendalian umum pengamanan sistem informasi untuk memastikan akurasi dan kelengkapan informasi yang memperhatikan penetapan organisasi untuk implementasi, pemantauan efektivitas program pengamanan gitu."

Dengan melihat pernyataan diatas pada Dinas Sosial Provinsi Lampung, terdapat kegiatan pengendalian umum pengamanan sistem informasi untuk memastikan akurasi dan kelengkapan informasi yang memperhatikan: Penetapan organisasi untuk implementasi, pemantauan efektivitas program pengamanan.

d. Pengendalian fisik atas asset

Pada Dinas Sosial Provinsi Lampung, terdapat pengendalian fisik atas asset yang telah ditetapkan oleh Pimpinan Instansi Pemerintah diimplementasikan dan dikomunikasikan kepada seluruh pegawai.

e. Penetapan dan reviu atas indikator dan ukuran kinerja

Pada Dinas Sosial Provinsi Lampung, melakukan reviu dan validasi secara periodic atas ketetapan dan keandalan ukuran dan indikator kinerja.

\section{f. Pemisahan Fungsi}

Pada Dinas Sosial Provinsi Lampung, terdapat pemisahan fungsi yang menjamin bahwa seluruh aspek utama transaksi atau kejadian tidak dikendalikan oleh 1 (satu) orang yang ditandai dengan pemisahan tanggung jawab dan tugas atas transaksi atau kejadian terkait dengan otorisasi, persetujuan, pemrosesan dan pencatatan, pembayaran atau penerimaan dana, reviu dan audit serta fungsi-fungsi penyimpanan dan penanganan aset.

g. Otorisasi atas transaksi dan kejadian penting

Pada Dinas Sosial Provinsi Lampung, terdapat otorisasi atas transaksi dan kejadian penting yang ditetapkan oleh pimpinan instansi pemerintah dan dikomunikasikan kepada seluruh pegawai hanya transaksi dan kejadian signifikan yang di entri adalah yang telah diotorisasi dan dilaksanakan hanya oleh pegawai sesuai lingkup otoritasnya.

h. Pencatatan yang akurat dan tepat waktu atas transaksi dan kejadian

Pada Dinas Sosial Provinsi Lampung, transaksi dan kejadian dklasifikasikan dengan tepat dan 
dicatat segera dalam seluruh siklus transasksi atau kejadian.

i. Pembatasan akses atau sumber daya dan pencatatannya

Pada Dinas Sosial Provinsi Lampung, akses hanya diberikan kepada pegawai yang berwenang dan pimpinan instansi pemerintah melakukan reviu atas pembatasan tersebut secara berkala dengan mempertimbangkan faktor-faktor seperti nilai asset, kemudian dipindahkan, kemudian ditukarkan.

j. Akuntabilitas terhadap sumber daya dan pencatatannya

Pada Dinas Sosial Provinsi Lampung, terdapat penetapan akuntabilitas terhadap sumber daya dan pencatatannya dengan menunjuk petugas yang bertanggungjawab terhadap penyimpanan sumber daya dan pencatatannya, pimpinan instansi melakukan reviu atas penugasan tersebut secara berkala dan peril dinilai pertanggungjawaban dan akuntabilitasnya.

k. Dokumentasi yang baik atas sistem pengendalian internal serta transaksi dan kejadian penting

Pada Dinas Sosial Provinsi Lampung, terdapat dokumentasi yang baik atas sistem pengendalian internal serta transaksi dan kejadian penting yang diwujudkan dengan cara memiliki, mengelola, memelihara, dan secara berkala memutakhirkan dokumentasi tersebut.

\section{Informasi dan Komunikasi}

Unsur SPIP berikutnya adalah informasi dan komunikasi. Sehubungan dengan definisi tersebut, maka PP Nomor 60 Tahun 2008 mengatur bahwa untuk menyelenggarakan informasi dan komunikasi yang efektif. Pada Dinas Sosial Provinsi Lampung, memastikan terjalinnya komunikasi eksternal yang efektif, yaitu untuk mengetahui berfungsinya pengendalian internal dan menginformasikan mengenai kode etik yang berlaku dengan menggunakan berbagai bentuk dan sarana dalam mengkomunikasikan informasi penting.

\section{Pemantauan}

Unsur terakhir dari SPIP adalah pemantauan pengendalian intern Pemantauan berkelanjutan, evaluasi terpisah dan tindak lanjut rekomendasi hasil audit dan reviu lainnya. Berdasarkan pernyataan Ibu Haveana : "Ya, sudah dilaksanakan adapun kegiatan monitoring/control pengelolaan rutin terkait dalam pelaksanaan tugas baik oleh atasan langsung maupun control dalam bentuk koordinasi antar bidang untuk memberikan masukan-masukan, pemanggilan secara langsung oleh kepala dinas. Nah itu tiap tahun kita lakukan control terhadap pelaksanaan kegiatan dibawah itu tiap tahunnya."

Pemantauan diselenggarakan melalui kegiatan monitoring/kontrol pengelolaan rutin terkait dalam pelaksanaan tugas baik oleh atasan langsung maupun kontrol dalam bentuk koordinasi antar bidang untuk memberikan masukan-masukan, pemanggilan secara langsung oleh kepala dinas jika membutuhkan informasi terkait dengan permasalahan yang ada sehingga untuk meminimalisir penyimpangan dan efektifitas pencapaian tujuan organisasi. 


\section{KESIMPULAN}

\section{Kesimpulan}

Berdasarkan hasil penelitian dan pembahasan yang dilakukan, maka dapat disimpulkan bahwa :

1. Sistem pengendalian internal yang diterapkan oleh Dinas Sosial Provinsi Lampung telah efektif dan memadai.

2. Pembagian wewenang dan tanggung jawab sudah efektif dilakukan oleh Dinas Sosial Provinsi Lampung.

3. Realisasi belanja Dinas Sosial Provinsi Lampung sudah efektif, namun kurang efektifnya dalam pencapaian indikator kinerja.

4. Kurangnya SDM dalam pencapaian indikator kinerja.

\section{Saran}

Berdasarkan hasil penelitian, pembahasan, dan kesimpulan yang diperoleh, maka saran yang dapat diberikan adalah sebagai berikut:

1. Sebaiknya Dinas Sosial Provinsi Lampung membentuk badan audit Pengendalian Internal dinas yang bertugas untuk mengaudit segala kinerja dinas dan mempersiapkan dinas dalam pengawasan eksternal.

2. Sebaiknya dinas lebih memperhatikan jumlah sumber daya manusia yang ada di setiap bidang yang masih membutuhkan tambahan pegawai demi peningkatan kinerja dinas.

\section{DAFTAR PUSTAKA}

Anindita, Primastuti. 2006. Kualitas Sistem Pengendalian Intern Sebagai Penentu Tingkat Kepercayaan
Laporan Keuangan Suatu PemerintahDaerah. Widyapraja, Vol.32, No. 3.

Azhar, Susanto. 2010. Sistem Informasi I, Pendekatan Normal Praktiuka Penyusunan Metode dan Prosedur, Edisi 5. Bandung : Lingga Jaya.

Bastian, Indra. 2010. Akuntansi Sektor Publik Edisi Ketiga. Jakarta: Erlangga.

Hery. 2014. Akuntansi Dasar 1 dan 2. Jakarta: Kompas Gramedia.

Julia Christina, Turagan. 2017. Evaluasi Sistem Pengendalian Intern (Internal Control) Terhadap Kinerja Dinas Pekerjaan Umum Provinsi Sulawesi Utara. 963 976.

Moeller, R. R. 2008. Sarbanes-Oxley Internal Controls: Effective Auditing with AS5, CobiT, and ITIL. John Wiley and sons, Inc. New Jersey.

Pertiwi, Dian. 2016. "Implementasi Sistem Pengendalian Intern Pemerintah (SPIP) Dalam Mewujudkan Good Governance Pada Dispenda Provinsi Sulawesi Selatan".

Ramandei, P. 2009. Pengaruh Karakteristik Sasaran Anggaran dan Sistem Pengendalian Intern Terhadap Kinerja Manajerial Aparat Pemerintah Daerah (Studi Empiris Pada Satuan Kerja Perangkat Daerah Kota Jayapura). Program Pasca Sarjana Magister Akuntansi, Universitas Diponegoro. Semarang

Ranatariza dan Noor. 2013. "Sistem Informasi Akuntansi Pada Aplikasi 
Administrasi Bisnis”. Malang : UB

Press.

Robbins, Stephen P. 2003. Perilaku Organisasi. Jakarta: Indeks.

Sugiyono. 2013. Metode Penelitian Kuantitatif dan Kualitatif dan $R \& D$. Bandung: Alfabeta.

Torang, Syamsir. 2013. Organisasi dan Manajemen ( Perilaku, Struktur, Budaya dan Perubahan Organisasi. Bandung: Alfabeta.

Utoyo, Bambang. 2017. Perkembangan Konsep Internal Control Versi COSO. Warta Pengawasan: Membangun Good Governance Menuju Clean Government, Vol. XVIII/No. 4 Desember 2011. ISSN: 0854-0519. Pp. 50-51. 